\section{Controlled-release Fertilizer for Vegetable Production: The California Experience}

\author{
T.K. Hartz ${ }^{1,3}$ and R.F. Smith ${ }^{2}$
}

ADDITIONAL INDEX WORDS. nitrogen, leaching, fertilizer efficiency

SUMMARY. Research on controlled-release fertilizers (CRF) in vegetable production has been conducted in California for several decades, and commercial CRF products have been marketed throughout most of that time. CRF remain niche products used on only a small percentage of vegetable fields. The potential advantage of CRF is maximized in production systems in which in-season nitrogen $(\mathrm{N})$ leaching is significant but beyond the control of the grower, and where there are cultural constraints on in-season fertilizer application. Neither of those conditions is typical of the California industry. Annual rainfall in the major vegetable-producing regions averages less than $400 \mathrm{~mm}$, with the majority of that received during winter months when vegetable production is limited; in-season leaching occurs almost exclusively from irrigation. The alluvial soils favored for vegetable production tend to be relatively fine-textured, with high water holding capacity that reduces $\mathrm{N}$ leaching potential. The widespread adoption of drip irrigation allows for efficient irrigation and for multiple applications of less expensive $\mathbf{N}$ fertilizers in synchrony with crop demand. Under representative California field conditions it has been difficult to show a horticultural benefit from the use of CRF, and the higher cost of these products has therefore limited their use. Future government regulation for water quality protection may require more efficient $\mathbf{N}$ fertilization practices, but significant expansion of CRF use is unlikely even under that scenario.

$\mathrm{R}$ esearch on the use of controlled-release fertilizers (CRF) in California vegetable production has been conducted for more than 30 years. Since Lorenz et al. (1972) evaluated CRF for potato (Solanum tuberosum), tomato (Solanum lycopersicum), and muskmelon (Cucumis melo) production, numerous university and industry trials have been conducted in California on a wide range of crops. Despite this extensive evaluation, CRF are currently used on only a small fraction of the state's vegetable acreage. This minimal utilization can be attributed to the higher cost of CRF as well as to the environmental conditions and field management practices characteristic of the California vegetable industry.

Although a number of types of CRF have been developed [methylene urea, isobutylenediurea (IBDU), sulfur-coated urea, and polymercoated fertilizers], one common characteristic is the significantly higher cost compared with conventional $\mathrm{N}$ fertilizers. Commercially available

\footnotetext{
${ }^{1}$ Department of Plant Sciences, University of California, 1 Shields Avenue, Davis, CA 95616

${ }^{2}$ University of California Cooperative Extension, Salinas, CA 93901

${ }^{3}$ Corresponding author. E-mail: tkhartz@ucdavis.edu.
}

CRF products have often been as much as twice the cost of conventional fertilizer per unit of $\mathrm{N}$, although advances in coating technology have lowered the cost disparity for some newer products. Therefore, voluntary grower adoption of CRF use has depended upon increased crop productivity or increased $\mathrm{N}$ uptake efficiency, allowing $\mathrm{N}$ rates to be reduced. Including CRF use as a government-sanctioned best management practice (BMP) for water quality protection would provide an additional incentive. However, mandatory water quality BMPs have not yet been established in California, and due to the lack of demonstrated value under California conditions, the use of CRF has not even been included in suggested nutrient BMPs (Pettygrove et al., 2005).

The potential advantage of CRF is maximized when in-season $\mathrm{N}$ leaching potential is significant. Many studies documenting CRF benefits were conducted on sandy soils and in environments receiving significant in-season precipitation; CRF research on potato production in Florida (Hutchinson, 2005; Hutchinson et al., 2003 ) and Minnesota (Zvomuya and Rosen, 2001) fit this profile. Likewise, the value of CRF for citrus (Citrus spp.) production in Florida (Obreza and Rouse, 1993, 2006; Paramasivam et al., 2001) has been attributed in large part to reduced $\mathrm{N}$ leaching potential in the sandy soils and high rainfall characteristic of the production areas.

In the main vegetable production areas of California (the central coast, and the San Joaquin and Imperial valleys), rainfall is rarely sufficient to cause significant leaching. Figure 1 shows monthly mean precipitation from a representative location in each area (University of California, 1983). In the Imperial Valley, no month averages more than 0.5 inch. In the San Joaquin Valley, mean monthly precipitation exceeds 1.0 inch only in January and February, a period with very limited vegetable production. Only along the central coast is the mean precipitation sufficient to cause extensive leaching, and rainfall is concentrated in the winter months when relatively few vegetable fields are under cultivation. In California, in-season leaching is primarily caused by irrigation management, not precipitation, and therefore is largely within the grower's ability to control.

Inefficient irrigation does occur. Historically, CA vegetable production was sprinkler- or furrow-irrigated, techniques that often have poor water distribution uniformity. Hanson (1995) reported that fieldscale sprinkler or furrow irrigation often achieved a distribution uniformity $<75 \%$. This level of irrigation inefficiency does result in $\mathrm{N}$ leaching, but California soil characteristics tend to reduce $\mathrm{N}$ leaching potential. $\mathrm{N}$ leaching potential from irrigation is greatest in soils with low water holding capacity and rapid water infiltration. In contrast to many vegetable production areas elsewhere in the United States, the major California production areas are dominated by

\begin{tabular}{llll}
\hline $\begin{array}{l}\text { Units } \\
\begin{array}{l}\text { To convert U.S. to SI, } \\
\text { multiply by }\end{array}\end{array}$ & U.S. unit & SI unit & $\begin{array}{l}\text { To convert SI to U.S., } \\
\text { multiply by }\end{array}$ \\
\hline 25.4 & inch(es) & $\mathrm{mm}$ & 0.0394 \\
1.1209 & lb/acre & $\mathrm{kg} \cdot \mathrm{ha}^{-1}$ & 0.8922 \\
1 & $\mathrm{ppm}$ & $\mathrm{mg} \cdot \mathrm{L}^{-1}$ & 1
\end{tabular}




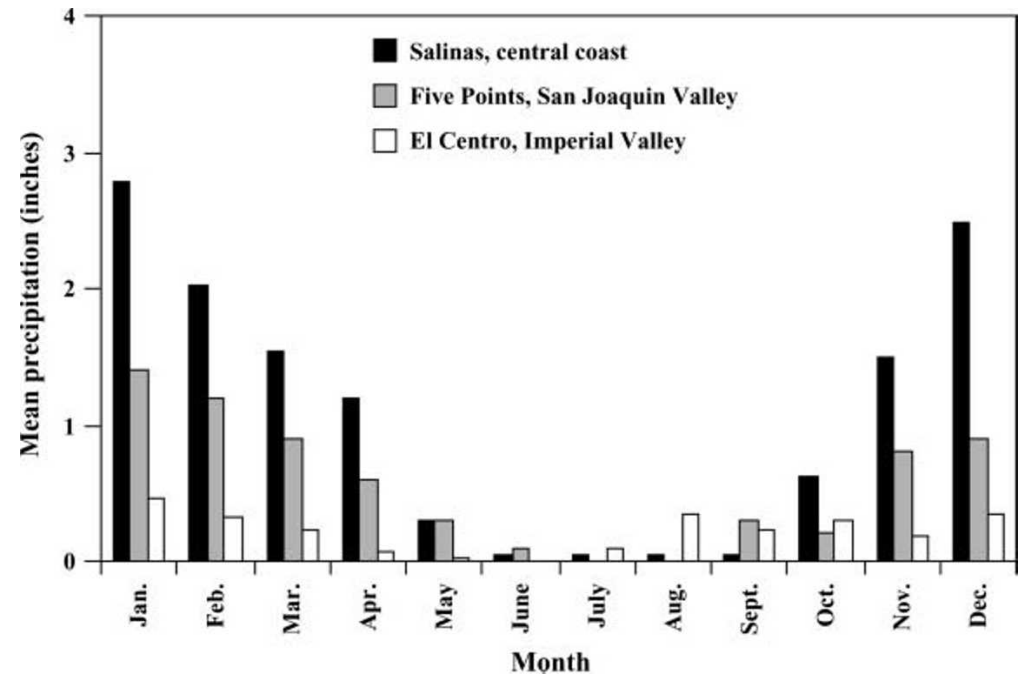

Fig. 1. Mean monthly precipitation for representative locations in the major vegetable-producing regions of California. Data are 30-year averages (University of California, 1983); 1 inch $=25.4 \mathrm{~mm}$.

soils of medium to heavy texture, with correspondingly high water holding capacity and moderate to slow water infiltration rate. Hartz and Johnstone (2005) collected soils from 25 representative coastal fields in long-term vegetable rotations; soils of loam and clay loam texture predominated. Similarly, of San Joaquin Valley processing tomato fields surveyed by Hartz et al., (1999), most were loam or heavier texture. Another factor mitigating in-season $\mathrm{N}$ leaching potential from California vegetable fields is the nearly universal practice of minimizing preplant $\mathrm{N}$ application and using sidedress $\mathrm{N}$ application. Depending on the crop, as many as three or four sidedressings may be applied throughout the season, which limits $\mathrm{N}$ leaching potential.
Furthermore, irrigation practices are changing. To improve irrigation efficiency as well as to increase yield, many California vegetable growers are converting fields to drip irrigation. With drip irrigation, distribution uniformity $>90 \%$ can be obtained on a field scale. Drip irrigation also removes cultural limitations on inseason $\mathrm{N}$ application; multiple $\mathrm{N}$ fertigations are commonly used to apply $\mathrm{N}$ in synchrony with plant $\mathrm{N}$ uptake. Currently, more than $30 \%$ of coastal vegetable acreage is drip-irrigated, up from less than $10 \%$ a decade ago. Utilization of drip irrigation is increasing rapidly in the San Joaquin Valley as well, with more than a third of tomato acreage now under drip cultivation. Statewide, the pace of conversion of vegetable production to drip irrigation is accelerating; it is likely that the majority of California vegetable acreage will be drip-irrigated within a decade. As the utilization of drip increases, irrigation efficiency and $\mathrm{N}$ fertigation will reduce the likelihood of significantly expanded CRF use.

Environmental concern over nutrient loss from vegetable fields is a factor stimulating interest in CRF (Hutchinson et al., 2003; Zvomuya and Rosen, 2001). In California, it is in the central coast region where interest in CRF has been strongest and the current limited use of CRF is centered. In this region, decades of intensive vegetable production have resulted in a significant $\mathrm{N}$ pollution problem affecting groundwater and surface water. Many bodies of water in this region have a nitrate-nitrogen $\left(\mathrm{NO}_{3}-\mathrm{N}\right)$ concentration in excess of the Federal drinking water standard of $10 \mathrm{mg} \cdot \mathrm{L}^{-1}$. Regulatory pressure on coastal growers to improve nutrient management is building. In theory, the use of CRF could be a valuable tool.

The primary vegetable production period for the central coast region is March through October; the vast majority of vegetable fields are fallow for most of the November through March period when leaching rainfall is most likely (Fig. 1). To date, CRF research has targeted the minority of fields under cultivation during the winter rainy season. Table 1 summarizes nine commercial field trials conducted under representative coastal conditions, comparing $\mathrm{N}$ fertilization regimes using $\mathrm{CRF}$ and conventional fertilizers. In each trial,

Table 1. Results of controlled-release fertilizers (CRF) for winter vegetable production under California coastal conditions.

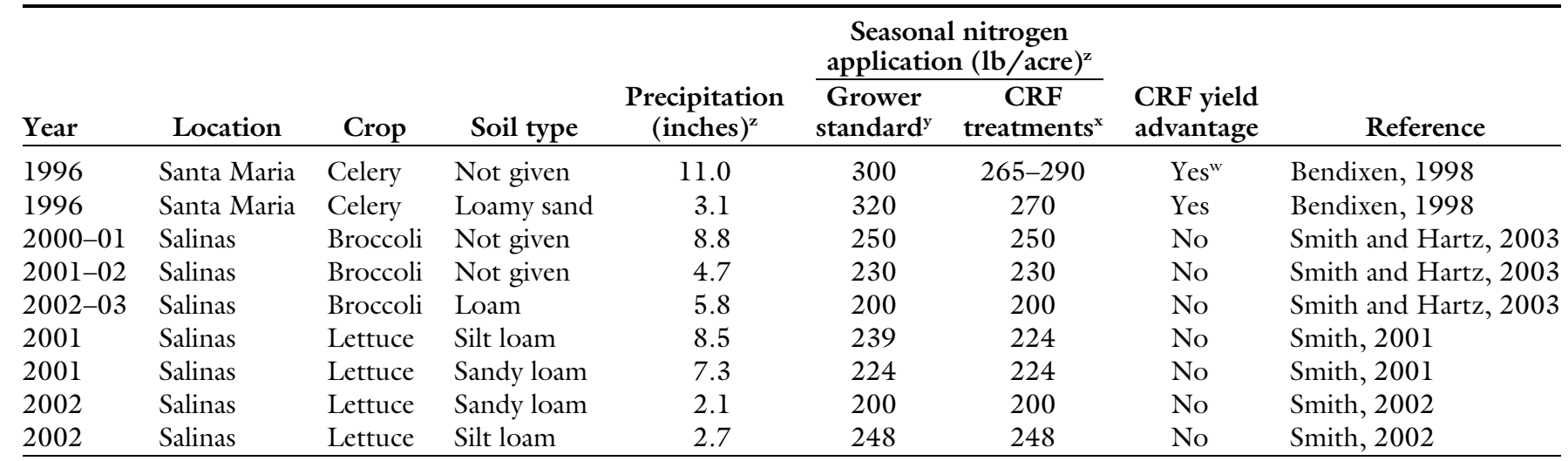

${ }^{\mathrm{z}} \mathrm{l}$ inch $=25.4 \mathrm{~mm} ; \mathrm{llb} /$ acre $=1.1209 \mathrm{~kg} \cdot \mathrm{ha}^{-1}$.

Includes preplant and sidedress nitrogen $(\mathrm{N})$ application of soluble $\mathrm{N}$ fertilizer.

${ }^{\mathrm{x}}$ All trials included preplant CRF treatments alone, and in combination with in-season application of soluble $\mathrm{N}$ fertilizer.

wOne or more treatments using CRF resulted in significantly higher yield $(P<0.05)$ than the grower's regimen of soluble $\mathrm{N}$ application. 
the grower standard fertilization practice (no CRF) was compared with treatments using preplant CRF alone or in combination with sidedressed conventional $\mathrm{N}$ fertilizer.

The use of CRF resulted in a significant crop yield response only in the two celery (Apium graveolens var. $d u l c e$ ) trials. The crop response in the first celery trial was undoubtedly related to the abnormally high rainfall received during that trial (more than $40 \%$ above normal). The factors responsible for the crop response in the second trial are less clear; presumably, the combination of sandy soil texture and inefficient irrigation resulted in significant leaching and insufficient $\mathrm{N}$ availability for at least part of the season in the grower standard plots. More typical of the California experience with CRF were the broccoli (Brassica oleracea var. italica) and lettuce (Lactuca sativa) trials in which no yield advantage was observed at any of the seven sites. The lack of agronomic response to CRF use in the lettuce and broccoli trials may be attributed to several factors. The grower standard practice used high $\mathrm{N}$ fertilization rates, with $\mathrm{N}$ applied preplant and in multiple sidedressings (as is normal in the industry), thus the likelihood of even a transient $\mathrm{N}$ deficiency was remote. Also, Winter 200102 was abnormally dry.

The failure of CRF to consistently improve crop productivity, even under winter conditions most conducive to $\mathrm{N}$ leaching, has limited grower interest in this technology from a horticultural perspective. The potential environmental benefits of CRF use have not been extensively evaluated under representative coastal field conditions. While there is little doubt that intelligent use of CRF could reduce $\mathrm{N}$ loss to the environment compared with current fertilization practices, it is not clear that CRF use would be the most efficient or cost-effective way to reduce $\mathrm{N}$ pollution potential.

As outlined by Hartz (2006), there are several BMPs that coastal growers could employ to drastically reduce $\mathrm{N}$ usage in vegetable production without incurring the added costs of CRF. First, employing seasonal $\mathrm{N}$ rates in line with crop $\mathrm{N}$ uptake could cut $\mathrm{N}$ application in some fields in half. Breschini and Hartz (2002) reported seasonal rates for lettuce as high as $338 \mathrm{lb} /$ acre $\mathrm{N}$, while lettuce seasonal $\mathrm{N}$ uptake averaged less than $120 \mathrm{lb} /$ acre (Hartz et al., 2000). Second, pre-sidedress soil nitrate testing (PSNT) could identify fields in which sidedressing could be delayed or reduced; across 26 commercial field trials, PSNT reduced seasonal $\mathrm{N}$ application to lettuce by $>40 \%$ (Breschini and Hartz, 2002; Hartz et al., 2000). Lastly, conversion to drip irrigation can drastically reduce in-season leaching volume and allow $\mathrm{N}$ application in synchrony with crop uptake, further reducing $\mathrm{N}$ leaching potential.

In summary, CRF is most appropriately employed in field situations in which significant in-season leaching is likely, but beyond the control of the grower. Such situations in the California vegetable industry are uncommon. CRF use is unlikely to expand substantially unless CRF becomes more cost-competitive with other fertilizers, or environmental regulatory pressure provides an additional incentive for use.

\section{Literature cited}

Bendixen, W.E. 1998. Evaluation of controlled release fertilizers for fertigation in strawberries and vegetables. Project 95-0418 Final Report. California Dept. Food Agr. Fert. Res. Educ. Program, Sacramento.

Breschini, S.J. and T.K. Hartz. 2002. Presidedress soil nitrate testing reduces nitrogen fertilizer use and nitrate leaching hazard in lettuce production. HortScience 37:1061-1064.

Hanson, B.R. 1995. Practical potential irrigation efficiencies. Proc. 1st Intl Conf., Water Resources Eng. Div., Amer. Soc. Civil Eng., San Antonio, TX, 14-18 Aug. 1995. p. 1580-1584.

Hartz, T.K. 2006. Vegetable production best management practices to minimize nutrient loss. HortTechnology 16:398-403.

Hartz, T.K. and P.R. Johnstone. 2005. Relationship between soil phosphorus availability and $\mathrm{P}$ loss potential in runoff and drainage. Commun. Soil Sci. Plant Anal. 37:1525-1536.

Hartz, T.K., G. Miyao, R.J. Mullen, M.D. Cahn, J. Valencia, and K.L. Brittan. 1999. Potassium requirements for maximum yield and fruit quality of processing tomato. J. Amer. Soc. Hort. Sci. 124: 199-204.

Hartz, T.K., W.E. Bendixen, and L. Wierdsma. 2000. Pre-sidedress soil nitrate testing as a nitrogen management tool in irrigated vegetable production. HortScience 35:651-656.

Hutchinson, C.M. 2005. Influence of a controlled-release nitrogen fertilizer program on potato (Solanum tuberosum L.) tuber yield and quality. Acta Hort. 684: 99-102.

Hutchinson, C., E. Simonne, P. Solano, J. Meldrum, and P. Livingston-Way. 2003. Testing of controlled release fertilizer programs for seep irrigated irish potato production. J. Plant Nutr. 26:17091723.

Lorenz, O.A., B.L. Weir, and J.C. Bishop. 1972. Effect of controlled-release nitrogen fertilizers on yield and nitrogen absorption by potatoes, cantaloupes and tomatoes. J. Amer. Soc. Hort. Sci. 97: 334-337.

Obreza, T.A. and R.E. Rouse. 1993. Fertilizer effects on early growth and yield of 'Hamlin' orange trees. HortScience 28:111-114.

Obreza, T.A. and R.E. Rouse. 2006. Long-term response of 'Hamlin' orange trees to controlled-release nitrogen fertilizer. HortScience 41:423-426.

Paramasivam, S., A.K. Alva, A. Fares, and K.S. Sajwan. 2001. Estimation of nitrate leaching in an Entisol under optimum citrus production. Soil Sci. Soc. Amer. J. 65:914-921.

Pettygrove, S., T. Hartz, R. Smith, T. Lockhart, B. Hanson, L. Jackson, and S. Grattan. 2005. Nutrient management goals and management practices for cool-season vegetables. Univ. California Publ. 8097.

Smith, R. 2001. Evaluation of controlled release fertilizers for winter lettuce production. California Lettuce Res. Board Annu. Rpt. p. 243-249.

Smith, R. 2002. Evaluation of controlled release fertilizers for winter lettuce production. California Lettuce Res. Board Annu. Rpt. p. 183-191.

Smith, R. and T. Hartz. 2003. Evaluation of slow release fertilizers for cool-season vegetable production in the Salinas Valley. Project 00-0506 Final Report. California Dept. Food Agr. Fert. Res. Educ. Program, Sacramento.

University of California. 1983. Average daily air temperatures and precipitation in California. Univ. California Spec. Publ. 3285 .

Zvomuya, F. and C.J. Rosen. 2001. Evaluation of polyolefin-coated urea for potato production on a sandy soil. HortScience 36:1057-1060. 